報を発する装置を考案した，本院では，自現機の Film 走行異常によるトラブルが発生しても，との装置により， 早期に検知出来， ロス Film を出さずに済んでいるので 報告する。

\section{EMI Scannerについて}

熊本大学医学部付属病院中央放射線部

○田端 哲之・岡田・武雄・野崎 征洋

平田 幸德・守部 伸幸

[目的]

ファントムの試作, EMI NUMBER とマトリックス 成分との関係, 分解能測定.

[結果]

ファントムの試作では円柱形に加工する事，均一な EMI NUMBER（10〜50)，をもつ物質の入手が難しい 等から，アクリル樹脂でファントムを製作した。同一マト リックスに EMI NUMBER の異なる物質が共存する時, 合成 EMI NUMBER は水そうファントム内でアクリル 板を前後させる方法; 造影剤濃度を変化させる方法加ら, 成分物質 EMI NUMBER を成分比に比例配分したもの となった. 分解能測定ではアクリルファントム内の径 1 $\sim 4 \mathrm{~mm}$ の管に造影剤を入れ Scan し，肉眼的に観察し た結果，造影剂 EMI UNMBER がベースより低い時 2 $\mathrm{mm}$ 迄，高い時 $1 \mathrm{~mm}$ 迄識別する事が出来た.

\section{質問}

EMI Scannerの精度を評価する場合使用するファン トムの製作は，今まで用いていたX線用ファントムのよ うに簡単にい加ないということであったが，どのような ファントムが良いのか教えて下さい。

田中，高生（福岡）

\section{答}

X線用ファントムでは，ファントム物質のX線吸収率 迄，神経質に考慮する必要はなく，単に使用するに一番 使いやすい，大きさになる物質がファントム材として使 わ机てきた.CF Scannerでは,マトリックスの大きさの X線吸収值が問題となる為，ファントム材料の選別がむ つかしくなる，その他，実験目的に応じたファントム製 作はX線用ファントムの様に簡単にばいかない様に思い ます：現在の所，何が一番よいかが，全く検討がつかな いとしかいえません。

\section{3. 二重曝射防止装置}

熊本大学医学部咐属病院中央放射線部

○守部：伸幸・岡田 武雄・田端 㫪之

ブッキーテーブル等のカヤッテホルダ内に於汁るカセ ッテの状態を，制御盤上に表示し，且つ，自動的䎲，二
重暴射及び空曝射を防止するあので，カセッテを挿入 すると，未撮影カセッテ㨂入済表示ランプが点灯し， Xray ・Ready 回路を閉じ，撮影可能となる. 次に，撮影 が完了すると，撮影済表示ランプが点灯し，X-ray： Ready 回路を開き，二重曝射を防此する，カセッテをブ ッキーテーブルから拔き出すと，空表示ランプが点灯し， その時す X-ray・Ready 回路は開いている.との様にイ ンターロック方式なので, 複数の技師加, 複数の装置を 担当しているととろでは，カセッテ交換等によるミスが 防げ非常に有益である。

(シンポシウム)

\section{医療被曝の軽減について（主としてフィルムと增感紙）}

\section{1. 骨撮影と感光材料}

新小倉病院放射線室 柴田”清秀

医療被曝軽減の具体論の一つとして感光材料に関する うち骨撮影での具体論. 即ちどの組合せの感光材料末で 画筫上許されるか，につき検討した。

[方法]

代表的と考えられる頭部撮影亡腰椎撮影飞つき骨入り ファントムを用い約55組の組合せ写真を撮影し（Dう 1.2), チャート法・因眼による判定・粒状性等より総合 判定をした：粒状性・特性曲線の問題も検討した。

[結論]

(1)レギュラータイプのフイルムは幾何学的不鋭の少な い条件を選べば，LH-I まで画質上許される. (2)オルン タイプは粒状性の面から少数ではあるが否定する意見が ある. が幾何学的不鋭の少ない条件で $1 / 7,1 / 10$ のタイ プのものまで一応許されるという意見が多い。

\section{2. 被曝線量の低減（造影系について）}

熊本大学医学部附属診療放射線技師学校 吉田日出輝

熊本大学医学部附属病院中央放射線部

鈴木 有二・河野 直久・洞田貫誠志

平田幸徳

緒方放射線科医院 柇浦 龍登 結核予防会熊本県支部熊本健康相談所 魚住 敏郎

被曝線量の低減は今日の大きな問題であるが，乙れに は，画質の検討は不可欠な問題である. 我々は，現在の 画質を保方被曝線量をじの程度減少し得るか子検討し た. 感度特性と画質特性について検討し, 画質特性につ いては，主観的評価法之客観的評価法を用いた。上小

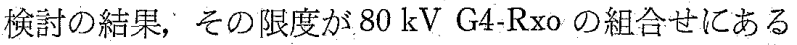
ことを見い出した，てれを立証するために，脳血管造影 